\title{
A Conversation with Felipe Criado Boado
}

Professor Criado-Boado's work is wide-ranging, encompassing landscape archaeology, rural bistory, community science, the transfer of knowledge, and applied archaeology as well as heritage. He has done research on origins and developments of monumental architecture (field work in Spain, Portugal, UK, Chile, Argentina, Peru and Uruguay) and rock art (field experience and research on Spain, Portugal, Scandinavia, and Chile). His approach is linked to Interpretive theory, pointing out the conditions of possibility of archaeological and cultural knowledge and defining a systematic methodological framework to base archaeological interpretation.

Alessandro Pintucci: Let's start from your occupation in Spain. Can you please tell us which kind of research INCIPIT carries on? Which is its mission, and if there is any research you are especially proud of. Which projects, for example, are in progress at this moment?

Felipe Criado-Boado: Thank you, Alessandro, and thank you for this question. It gives me the possibility to speak about my contextual basis, because our role both in research and as persons relies firstly on the context we came from. So let me quickly say a few words about the Institute of Heritage Sciences (INCIPIT) that belongs to the Spanish National Research Council (CSIC). INCIPIT is based in Santiago de Compostela, and this is interesting because we are located in the westernmost corner of Eurasia, it is not only the westernmost tip of Europe! We are an institute fully devoted to fundamental research with a strong sense of research applicability, aiming to be useful for society. It is a transversal institute that is joined around a common research problem, the "value chain of Heritage". So, we study the topic from how heritage becomes heritage to its public use, in other words the social use of Heritage. I must say that I find it extremely useful to build a research institute around a common scientific problem. Therefore, you put people from different disciplines together in order to tackle a problem from several perspectives. So, in INCIPIT we are not only a group of archaeologists, we also have anthropologists, historians, soil scientists, environmental scientists, even software engineers and cultural astronomers. Our common research problem allows systemic engagement, and the creation of transversal interests and cooperation between us.

You also asked about my research. I am mainly a Landscape archaeologist. Initially I focused on megalithism and monumental constructions, then I become interested on ritual and sacred landscapes. And as a result, I engaged with Heritage, and the public dimension of archaeology. My research also goes in the line of Critical Heritage Studies. From a pure archaeological point of view my work is still mainly about symbolic landscape. The main problem of my research is Space, how Space was thought and built. 
My approach is deployed form the general principle that spatial experiences and products are based on the very concept of Space every society has, something that I have proposed to name Xscape.

Right now, I feel fortunate because now I can approach this problem from a very ambitious perspective thanks to a recently funded project by the ERC Synergy Grant call. That provides us 10 million $€$ to develop the project during the next 6-7 years. This project is composed by archaeologists, such as me and Johannes Müller, another prominent member of EAA. Besides us there is a neuro-scientist specialized in visual cognition, and a cognitive philosopher. The project, entitled Material Minds (acronym XSCAPE), is about the interaction of cognition and materiality between mind and objects. In this project we will use archaeology and ethnoarchaeology as proxies to address the problem of cognition from a historic and trans-cultural perspective. Something that neither neurosciences nor cognitive sciences do, since they work on a present-day basis.

Alessandro Pintucci: This is your last year as the EAA President, Eszter Banffy succeeded you in the same capacity following last year's annual meeting: would you like to share with us your evaluation of the EAA association work so far? And, how did the EAA evolve during your presidential period?

Felipe Criado-Boado: The first thing I must say is that it was a privilege to serve the EAA in the position of president, which I envision as the first servant of the association. I feel proud of that, and I will work for the association as an ordinary member once the EAA becomes led by Eszter Banffy, who will be an extraordinary president.

The reason why I feel proud is because EAA is a "magic" organization, to my view it is magic. It has a lot of positive energies and also an extremely good mood. The best example of this is the annual meetings. These meetings continue to be intellectually provocative, very important in terms of practical achievements, but at the same time they are enjoyable. The annual EAA conference is a place to meet and a place to be.

It has to be said that in last years, even before I got the president position, EAA was growing quickly, and still is. Its relevance is also increasing, nowadays we are about 2500 members, depending on the place where the annual meeting is held; and most certainly we will be no less than 3000 , or perhaps 3500 members in the upcoming years. For this reason, in the last year, we worked to strengthen the organization and the quality of our services to members.

I feel quite happy about how the secretary and organization was buster in these complicated years. Moreover, EAA is a perfect area to break through the divides between different sorts of archaeological practice, and also an arena to create ideas in practice. EAA merges together archaeologists not only from Europe, or more importantly, from different research traditions across Europe, but also practitioners of the diverse types of archaeological practices. Archaeology, Heritage professionals, academics, museums, private companies, professional sector, public sector, public and community companies, all are together within EAA. That situation gives the organization a strong power to understand and negotiate the different experiences of archaeological practice, and create 
a collective intelligence of what we do in archaeology. Behind that, there are other important matters, which I will elaborate with an example I experienced years ago.

Once I met a group of very young people of different nationalities at the EAA meeting, I came to them, and asked: Why did you come here? I was aware of how expensive it is to attend the meeting regarding inscription, lodging, travel, etc, something that is more obvious for young colleagues. The answer they gave me was significant. They said: we came to the EAA because here everybody hears us, everybody in the audience gives us feedback, and you can talk to the big names of European archaeology in a very normal way. This answer made me proud about EAA, and also very sorry for them, because their answer also implied that they were not heard back at their domestic backgrounds.

Moreover, EAA is in the process of becoming a global entity, from several years ago EAA is also full of people from outside Europe. We are increasingly becoming a global agent. Therefore, I would say EAA is not about European archaeology, it is about bringing the best of European values to the archaeological practice, independently of where and how this practice is performed. Of course, we should be very critical about the European modern tradition and our values. After all, the patriarchal colonial capitalist system that has been hegemonic in the World for the last centuries, is an European product. It is our obligation now to decolonize and genderize both our thought and practice. But yet, Europe should defend the critical democratic values that it also produced and update them from the view of a reflexive or soft modernity.

Alessandro Pintucci: EAA was established to bring together Eastern and Western Europe, academic and commercial sectors and succeeded in this endeavor. Why in your opinion such an operation has not been as successful within individual countries with the very same agents?

Felipe Criado-Boado: This is an important question. We were trying to answer that for the last 25 years. The statement you're proposing is true and false at the same time. Let me explain quickly. It is true that many countries in Europe have not gotten yet this inclusive wave EAA is promoting and building itself. Besides that, in many countries you will find that huge part of the best of the Archaeological work and practice of these countries are within EAA. Some countries are doing better than others, for instance, Anglo-Saxon, and Scandinavian countries and recently also Germany are doing better than others, especially regarding Eastern Europe, and Mediterranean countries. Italy and Spain could do better, for sure. Why they don't do better? Perhaps because Archaeology in Italy and Spain is still anchored on traditional and empiricist tradition, and people is reluctant to adopt other trends. Nevertheless, the total number of Italy and Spain members within EAA is currently the $12 \%$ of EAA membership. These numbers cannot be compared to UK, but still. Besides Germany and Scandinavia, Italy and Spain are the better represented countries in EAA. Moreover, when you look at the average age of Italian and Spanish members is 43 years old, which is in my opinion a very young age regarding the global or European trends. We have a lot of young people, $\mathrm{PhD}$, early career researchers and postdocs, they are very dynamic and high-quality archaeology, but still have precarious 
working positions, temporal jobs, and are kept out of the main trends of power in Archaeology.

Alessandro Pintucci: Once your appointment as EAA president will end, you will most likely return to your institution, INCIPIT. Based on your experience, would you say that in Europe different archaeologies coexist, something we could term as a great divide between southern and northern countries? Summed to a divide between commercial and academic archaeology. We also interviewed Cornelius Holtorf who is working at Graduate School in Contract Archaeology (GRASCA). GRASCA is one of the few examples of an academic organization which aims to join commercial and academic spheres. His job works well in the Swedish context, but we might need more of this in the rest of Europe.

Felipe Criado-Boado: GRASCA is doing very well, it is the sort of project scheme that is really needed now; this is the first answer. But going into your question ... EAA managed to escape the strong divide between commercial and academic archaeology, however these divides are still out there. Traditionally, there were three big divides that still exist and are more visible in some countries.

The first divide is between Archaeology and Heritage. In this scenario Archaeology did quite well, and currently the interaction between Archaeology, scientific research and Heritage is more connected than it used to be in the past. The danger of a divide is still there, but we are doing well in that regard.

A second divide is between academic and professional sectors, this is a divide between thinkers and diggers, and again some countries did well negotiating the intersection between the two spheres. Cornelius is devoted to overcoming this divide. The third divide is North-South, or perhaps more importantly nowadays is the East-West divide.

Something that is very important ..., if we look at this from a pessimistic point of view, there are no signs that these divides will end soon. Let's be clear about this, both sides have a role in any divide. When you come to the southern countries many of our colleagues still prefer to maintain an old-fashion traditional and national perspective, instead of discussing common topics, interests and worries at an European scale. From an Anglo-Saxon point of view, this divide is also present, we should ask our northern colleagues to do better, in terms of knowing, hearing, reading what others do in different languages and different national traditions. There is a lot of good archaeology developed in other countries, not produced in English, but unknown by many. This is not a language problem, because even writing in English, these works remain unknown to Anglo-Saxon archaeologists. ... Begging your and their pardon..., British and North Americans should read and, moreover, quote more what we the others write and do.

Furthermore, there are new divides that many of us are worried about. The divide between Archaeological Science and Human and Social Archaeology, an Archaeology oriented to produce narratives and interpretation. Archaeological Science is very prominent today because it produces new data, new perspectives to problems, and even new questions. 
However, there is a danger that Archaeological Science will create a divide between them and Archaeology oriented to Social, Cultural and Public issues. We have also the divide between the conventional de-genderize Archaeology, that is then by definition implicitly male-chauvist, and an Archaeology informed by females and gender perspectives; this divide is so strong, that it not only provoked gender unbalance in Archaeology, but also affects archaeological interpretation by doing gender complexity invisible on the most of the current archaeological narratives.

Another arising divide is between Contemporary Archaeology, and the whole Archaeology. Contemporary Archaeology is extremely important nowadays, it is providing a number of new questions relevant for our societies. Partly because it is so new, that some people claim it is not archaeology. But it is! because they use archaeological methods and data. The matter is that this situation shows us that the divides are a product of our own development. New practices, new research, new approaches bring new things that could be received positively or negatively by current and old practitioners. When we push archaeology to do new things, we create the danger for new divides to arise. Initially this is not a problem! It is completely logical, but we will have to make room for everybody. My impression is that inclusiveness and being useful are the two more important things we could expect from archeologists, even in these difficult times of COVID when we all are quickly rising to a new-age or, better said, an epochal change.

We should use our knowledge of the past, the materials, the interaction between humans and materials, and between humans the world for that purpose. We should use all this knowledge and capabilities to be useful and counter the worrying future we are facing.

Alessandro Pintucci: Thank you very much! 
232 FELIPE CRIADO-BOAdo 